\title{
CONSUMPTION OF MARINE MAMMALS \\ BY BROADNOSE SEVENGILL SHARK NOTORYNCHUS CEPEDIANUS IN THE NORTHERN AND CENTRAL PATAGONIAN SHELF
}

\author{
A.C. Crespi-Abril ${ }^{1, *}$, N.A. García ${ }^{1}$, E.A. Crespo ${ }^{1}$ and M.A. Coscarella ${ }^{1}$
}

\begin{abstract}
The study of food habits of the broadnose sevengill shark (Notorynchus cepedianus) based on the observation of the stomach contents of 22 individuals, revealed the importance of marine mammals as part of the shark's diet. The analysis showed that marine mammals represent at least $30 \%$ of the total consumed biomass by broadnose sevengill sharks. The frequency of occurrence was estimated to be $35 \%$. The three pinnipeds with local distribution and at least two species of cetaceans were consumed. Although consumption of marine mammal was high, there was no evidence of direct attack on living preys by N. cepedianus, in Argentine waters.

Resumen - El estudio de la dieta del tiburón gatopardo (Notorynchus cepedianus) se basó en el análisis del contenido estomacal de 22 individuos y reveló la importancia de los mamíferos marinos como parte del consumo de los tiburones. Los análisis mostraron que los mamíferos marinos representan al menos el 30\% de la biomasa total consumida por el gatopardo. La frecuencia de ocurrencia porcentual se estimó en 35\%. Entre las especies consumidas se hallaron los tres pinnipedos con distribución local en la región y al menos dos cetáceos no identificados. A pesar que el consumo de mamíferos marinos fue importante, no existen referencias para el litoral argentino que indiquen que N. cepedianus ataque directamente a las presas vivas.
\end{abstract}

Key words: Notorynchus cepedianus, broadnose sevengill shark, feeding, stomach contents, marine mammals, Southwestern Atlantic Ocean.

\section{Introduction}

Shark predation on marine mammals has been reported worldwide. For example, Leatherwood et al. (1972) and Ainley et al. (1981) described attacks by sharks on many species of seals and dolphins off California. Cockcroft et al. (1989) mentioned predation by sharks on bottlenose dolphins (Tursiops truncatus) off Natal, South Africa. Brodie and Beck (1982) reported shark attacks on gray seals (Halichoerus grypus) in eastern Canada. Some authors suggested that shark predation may influence the marine mammal population dynamics. Such may be the case for the Hawaiian monk seal (Monachus schauinslandi), where shark predation is considered to be an important mortality factor (Kenyon, 1981). Ainley et al. (1985) speculated how this interaction could have influenced the population dynamics of the northern elephant seal (Mirounga angustirostris), by delaying the weaning of pups until the sharks are no longer concentrated around the breeding site. Würsig and Würsig (1980) also suggested that dusky dolphins (Lagenorhynchus obscurus) in Patagonia rest close to the shore, in order to avoid shark predation.

The broadnose sevengill shark (Notorynchus cepedianus) is one of the five shark species that frequently attack cetaceans (Heithaus, 2001). Praderi (1985) reported broadnose sevengill attacks on the franciscana dolphin (Pontoporia blainvillei) in Uruguayan waters, describing the species as a very voracious one. Ebert (1991a) also observed that this species heavily predates on marine mammals in South African waters.

$N$. cepedianus is a benthic and neritic species inhabiting the continental shelf in temperate seas in both hemispheres. It is common in shallow waters and sometimes it can be seen or caught close to the shore, but larger individuals are found in deeper waters (Compagno, 1984). According to this author, the maximum length recorded for the broadnose sevengill shark was $290 \mathrm{~cm}$. However, as he recognized, when he states that the species may reach up to $400 \mathrm{~cm}$ he may have confused with an old record of a bluntonse sixgill shark Hexanchus griseus.

Fragments of a southern elephant seal (Mirounga leonina) in the stomach of a broadnose sevengill shark in Patagonian waters is the only record suggesting that sharks may feed upon marine mammals in Argentina (Falabella et al., 1996²). Over the past few years, several sharks of this species were collected by sport fishing, the longline fishery for tope shark (Galeorhynus galeus) and as by-catch in the Argentine hake (Merluccius hubbsi) and Argentine red shrimp (Pleoticus muelleri) fisheries. The aim of this paper is to report new information regarding the consumption of marine mammals by broadnose sevengill sharks in Patagonia.

\section{Material and Methods}

The stomach contents of 22 broadnose sevengill sharks was analyzed. These individuals were captured as by-catch in the Argentine hake bottom trawl fishery $(n=10)$, Argentine red shrimp twin-beam trawl fishery $(n=4)$, tope shark longline fishery $(n=6)$ and fishing cane sport fishery $(n=1)$ (Table 1). In addition to our sample, we analyzed the contents of the individual studied by Falabella et al. (1996). The sharks were identified based on Compagno (1984) and Menni et al. (1984). They were sexed, weighed and measured in the Marine Mammals Laboratory (LAMAMA ${ }^{3}$ ). Finally, the sharks were dissected and the digestive tracts preserved frozen for further analysis.

\footnotetext{
${ }^{1}$ Laboratorio de Mamíferos Marinos, Centro Nacional Patagónico (CONICET) Boulevard Brown 3600 and Universidad Nacional de la Patagonia (UNP), Boulevard Brown 3700, (9120) Puerto Madryn, Chubut, Argentina.

*Corresponding author, e-mail: garcia@cenpat.edu.ar.

${ }^{2}$ Falabella, V., Lewis, M. and Elías, I. (1996) Registro de predación sobre una cría de elefante marino en Patagonia. Page 102 in Abstract, $7^{\text {a }}$ Reunión de trabajo de especialistas en mamíferos acuáticos de América del Sur, 22-25 October, Viña del Mar, Chile.

${ }^{3}$ Laboratorio de Mamíferos Marinos, Centro Nacional Patagónico (CONICET), Puerto Madryn, Chubut, Argentina.
} 
Table 1. Records of Notorynchus cepedianus specimens caught in Patagonian waters.

\begin{tabular}{|c|c|c|c|c|c|c|c|c|}
\hline $\begin{array}{l}\text { SPECIMEN } \\
\text { NUMBER }\end{array}$ & SEX & $\begin{array}{c}\text { LENGTH } \\
(\mathrm{cm})\end{array}$ & $\begin{array}{l}\text { WEIGHT } \\
(\mathrm{kg})\end{array}$ & $\begin{array}{c}\text { CAPTURE } \\
\text { DATE }\end{array}$ & LATITUDE & LONGITUDE & FISHING GEAR & AREA \\
\hline 1 & 우 & 224 & 57.95 & 08-Jan-96 & $43^{\circ} 40^{\prime} \mathrm{S}$ & $63^{\circ} 30^{\prime} \mathrm{W}$ & Bottom trawls & Continental shelf \\
\hline 2 & 우 & 201 & 35.00 & 28-Feb-96 & $43^{\circ} 00^{\prime} \mathrm{S}$ & $63^{\circ} 30^{\prime} \mathrm{W}$ & Bottom trawls & Continental shelf \\
\hline 3 & 우 & 197 & 39.10 & 09-Feb-96 & $43^{\circ} 59^{\prime} \mathrm{S}$ & $63^{\circ} 37^{\prime} \mathrm{W}$ & Bottom trawls & Continental shelf \\
\hline 4 & 오 & 181 & 26.50 & 13-Jun-97 & $46^{\circ} 10^{\prime} \mathrm{S}$ & $66^{\circ} 00^{\prime} \mathrm{W}$ & Twin-beam bottom trawls & Golfo San Jorge \\
\hline 5 & 오 & 210 & 36.50 & 03-Feb-98 & $45^{\circ} 30^{\prime} \mathrm{S}$ & $62^{\circ} 50^{\prime} \mathrm{W}$ & Bottom trawls & Continental shelf \\
\hline 6 & 오 & 158 & 13.25 & 16-Feb-98 & $44^{\circ} 05^{\prime} \mathrm{S}$ & $62^{\circ} 15^{\prime} \mathrm{W}$ & Bottom trawls & Continental shelf \\
\hline 7 & 오 & 159 & 16.00 & 13-Mar-98 & $46^{\circ} 10^{\prime} \mathrm{S}$ & $66^{\circ} 10^{\prime} \mathrm{W}$ & Twin-beam bottom trawls & Golfo San Jorge \\
\hline 8 & 오 & 210 & 35.00 & 20-Dec-98 & $45^{\circ} 05^{\prime} \mathrm{S}$ & $65^{\circ} 48^{\prime} \mathrm{W}$ & Twin-beam bottom trawls & Golfo San Jorge \\
\hline 9 & $\sigma^{\prime \prime}$ & 128 & 6.88 & 09-Dec-98 & - & - & Bottom trawls & Continental shelf \\
\hline 10 & $\sigma^{\prime \prime}$ & 167 & 18.57 & 28-Nov-99 & $42^{\circ} 49^{\prime} \mathrm{S}$ & $64^{\circ} 52^{\prime} \mathrm{W}$ & Sport fishing & Golfo Nuevo \\
\hline 11 & 오 & 210 & - & 25-Jan-00 & $45^{\circ} 14^{\prime} \mathrm{S}$ & $66^{\circ} 42^{\prime} \mathrm{W}$ & Twin-beam bottom trawls & Golfo San Jorge \\
\hline 12 & $\sigma^{\prime \prime}$ & 175 & 35.00 & 02-Dec-00 & $42^{\circ} 43^{\prime} \mathrm{S}$ & $64^{\circ} 56^{\prime} \mathrm{W}$ & Longline & Golfo Nuevo \\
\hline 13 & 우 & 126 & 7.99 & 19-Mar-02 & $42^{\circ} 11^{\prime} \mathrm{S}$ & $61^{\circ} 50^{\prime} \mathrm{W}$ & Bottom trawls & Continental shelf \\
\hline 14 & 우 & 215 & 47.00 & 11-Mar-01 & $42^{\circ} 43^{\prime} \mathrm{S}$ & $64^{\circ} 56^{\prime} \mathrm{W}$ & Longline & Golfo Nuevo \\
\hline 15 & 우 & 136 & 10.00 & 12-Mar-02 & $42^{\circ} 43^{\prime} \mathrm{S}$ & $64^{\circ} 56^{\prime} \mathrm{W}$ & Longline & Golfo Nuevo \\
\hline 16 & $\sigma^{\prime \prime}$ & 167 & 18.00 & 12-Mar-02 & $42^{\circ} 43^{\prime} \mathrm{S}$ & $64^{\circ} 56^{\prime} \mathrm{W}$ & Longline & Golfo Nuevo \\
\hline 17 & 오 & 147 & 11.25 & 12-Mar-02 & $42^{\circ} 43^{\prime} \mathrm{S}$ & $64^{\circ} 56^{\prime} \mathrm{W}$ & Longline & Golfo Nuevo \\
\hline 18 & 오 & 143 & 10.75 & 12-Mar-02 & $42^{\circ} 43^{\prime} \mathrm{S}$ & $64^{\circ} 56^{\prime} \mathrm{W}$ & Longline & Golfo Nuevo \\
\hline 19 & 오 & 162 & 17.15 & 23-Jan-03 & $45^{\circ} 20^{\prime} \mathrm{S}$ & $62^{\circ} 58^{\prime} \mathrm{W}$ & Bottom trawls & Continental shelf \\
\hline 20 & 오 & 244 & 90.00 & 16-Nov-02 & $42^{\circ} 58^{\prime} \mathrm{S}$ & $62^{\circ} 14^{\prime} \mathrm{W}$ & Bottom trawls & Continental shelf \\
\hline 21 & $\sigma^{\prime \prime}$ & 162 & 25.00 & 19-Mar-03 & - & - & Bottom trawls & Continental shelf \\
\hline $22^{*}$ & 우 & 244 & 97.00 & 14-Nov-95 & $43^{\circ} 22^{\prime} \mathrm{S}$ & $64^{\circ} 22^{\prime} \mathrm{W}$ & Bottom trawls & Continental shelf \\
\hline
\end{tabular}

$\left(^{*}\right)$ specimen obtained by Falabella et al. (1996); (-) no data available.

Food items were determined according to the methodology described by Koen Alonso et al. (1998). Prey species were identified and quantified from fish otoliths or bones, squid beaks, and crustacean exoskeletons by means of the LAMAMA reference collection and published catalogues (Clarke, 1986; Boschi et al., 1992; Volpedo and Echeverría, 2000). In order to estimate the total length and weight of preys (other than marine mammals), published regressions calculated by Koen Alonso et al. (1998) were applied. The biomass for a $51 \mathrm{~cm}$ chunk of tail of a scombrid (Scombridae) was estimated by comparison with reference material of the LAMAMA collection. Marine mammal remains in the stomach contents were weight as they were found, and identified by direct observation (bones and coloration of the skin for cetaceans and fur characteristics for pinnipeds). Samples of marine mammal tissue were collected and frozen $\left(-20^{\circ} \mathrm{C}\right)$ in order to identify the species through DNA analysis. For each prey item the percentage frequency of occurrence $(\% \mathrm{FO})$ was estimated following Cortés (1997). Homogeneity of the sample in terms of sexual maturity and sex composition was examined by means of a Fisher Exact Test. The lengths at sexual maturity used were $165 \mathrm{~cm}$ for males and $200 \mathrm{~cm}$ for female (Compagno, 1984).

\section{Results and Discussion}

Our sample consisted of 17 females with lengths ranging from 107 to $244 \mathrm{~cm}$; and of five males ranging from 128 to $175 \mathrm{~cm}$ (Table 1). This sample could be biased as a consequence of size or sex segregation, which is very common in many shark species (Compagno, 1984). However, no bias was found regarding sex nor sexual maturity (Fisher Exact Test $\mathrm{p}>0.5$ ).

Out of 22 stomachs examined, two were empty, seven contained marine mammals ( $35 \% \mathrm{FO})$ and 17 contained fishes and squids (85\%FO). Five stomachs presented marine mammal remains exclusively. Pinnipeds were found in five stomachs: South American sea lion (Otaria flavescens) ( $\mathrm{n}=3$ ), South American fur seal (Arctocephalus australis) $(\mathrm{n}=1)$ and southern elephant seal $(\mathrm{n}=1)$ (Table 2$)$. Cetaceans were found in three stomachs; however there is some degree of uncertainty in the species identification. Two of the samples containing cetaceans were taken at Golfo Nuevo $\left(42^{\circ} 43^{\prime} \mathrm{S}, 64^{\circ} 56^{\prime} \mathrm{W}\right)$ and one was collected at Golfo San Jorge $\left(45^{\circ} 14^{\prime} \mathrm{S}, 66^{\circ} 42^{\prime} \mathrm{W}\right)$. One of the sharks from Golfo Nuevo presented a small piece of cetacean remains (four pieces between 0.021 and $0.048 \mathrm{~kg}$ of muscle with bubbler) with black skin. Most species of cetaceans suffer 
a post-mortem darkening which makes difficult the identification of the species. This piece is likely to be from a dusky dolphin, due to the higher frequency of this species at Golfo Nuevo (LAMAMA, unpublished data). The other shark captured at Golfo Nuevo presented a thick piece of blubber (the measures were $10.5 \mathrm{~cm} \times 5 \mathrm{~cm} \times$ $4.8 \mathrm{~cm}$ and weight $0.15 \mathrm{~kg}$ ); probably belonging to a large cetacean. The most common large cetacean in the area is the southern right whale (Eubalaena australis) but there is no certainty about the identification of this species. The third sample with cetacean remains was collected from a shark caught at Golfo San Jorge. It was a tail $17.3 \mathrm{~cm}$ long, fluke width (tip to tip) $20.5 \mathrm{~cm}$ and weight $0.254 \mathrm{~kg}$ (Fig.1). This sample could belong either to a dusky dolphin, a Commerson's dolphin (Cephalorhynchus commersonii) or a Peale's dolphin (Lagenorhynchus australis), all of which are frequently seen in the area. Burmeister's porpoise was discarded due to the shape of the caudal vertebrae found in the stomach. Common and bottlenosed dolphins were also discarded as potential preys because they are not present in the area.
The total biomass of marine mammals found in the set of stomachs analyzed was $8.68 \mathrm{~kg}$, representing almost $30 \%$ of the total estimated consumed biomass. The South American sea lion accounted for $10.24 \%$ of the consumed biomass, the South American fur seal 6.7\%, the southern elephant seal $10.6 \%$, and all cetaceans combined only $1.82 \%$. The remaining percentage was fish and squid. However, this estimation could be negatively biased, because the biomass of marine mammals found in the stomachs was weighed directly, without regard for the biomass already digested. In three individuals, at least, the degree of digestion was very advanced, hence the weight of the pieces originally consumed was underrepresented (Table 2). On the other hand, the biomass of fish and squid consumed was estimated by means of regressions based on hard structures found in the stomachs. However, the frequency of occurrence of marine mammals could be overestimated because digestion time for these items is expected to be longer than for fishes, increasing the probability of the capture of a shark with marine mammal remains.

Table 2. Estimated consumed biomass for fishes and squids and weighed biomass for marine mammals found in stomach contents of Notorynchus cepedianus.

\begin{tabular}{|c|c|c|c|c|}
\hline $\begin{array}{l}\text { SPECIMEN } \\
\text { NUMBER }\end{array}$ & $\begin{array}{c}\text { BIOMASS IN GRAMS } \\
\text { (FISHES AND CEPHALOPODS) }\end{array}$ & $\begin{array}{l}\text { BIOMASS IN GRAMS } \\
\text { (MARINE MAMMALS) }\end{array}$ & CETACEANS & PINNIPEDS \\
\hline 1 & 1141 & - & & \\
\hline 2 & 1769 & - & & \\
\hline 3 & 3448 & - & & \\
\hline 4 & 3641 & - & & \\
\hline 5 & - & 1983 & & Arctocephalus australis \\
\hline 6 & 99 & - & & \\
\hline 7 & 600 & - & & \\
\hline 8 & 872 & - & & \\
\hline 9 & - & - & & \\
\hline 10 & + & - & & \\
\hline 11 & - & 648 & Small cetacean & Otaria flavescens \\
\hline 12 & - & $139^{*}$ & Small cetacean & \\
\hline 13 & 647 & - & & \\
\hline 14 & - & 2430 & & Otaria flavescens \\
\hline 15 & 4502 & - & & \\
\hline 16 & - & $223^{*}$ & & Otaria flavescens \\
\hline 17 & 168 & $150^{*}$ & Cetacea (blubber) & \\
\hline 18 & 124 & - & & \\
\hline 19 & 629 & - & & \\
\hline 20 & 1125 & - & & \\
\hline 21 & - & - & & \\
\hline 22 & 2255 & 3150 & & Mirounga leonina \\
\hline Total & 21023 & 8683 & & \\
\hline
\end{tabular}

$\left(^{*}\right)$ highly digested marine mammals' remains; $(+)$ no biomass back-calculation available. 


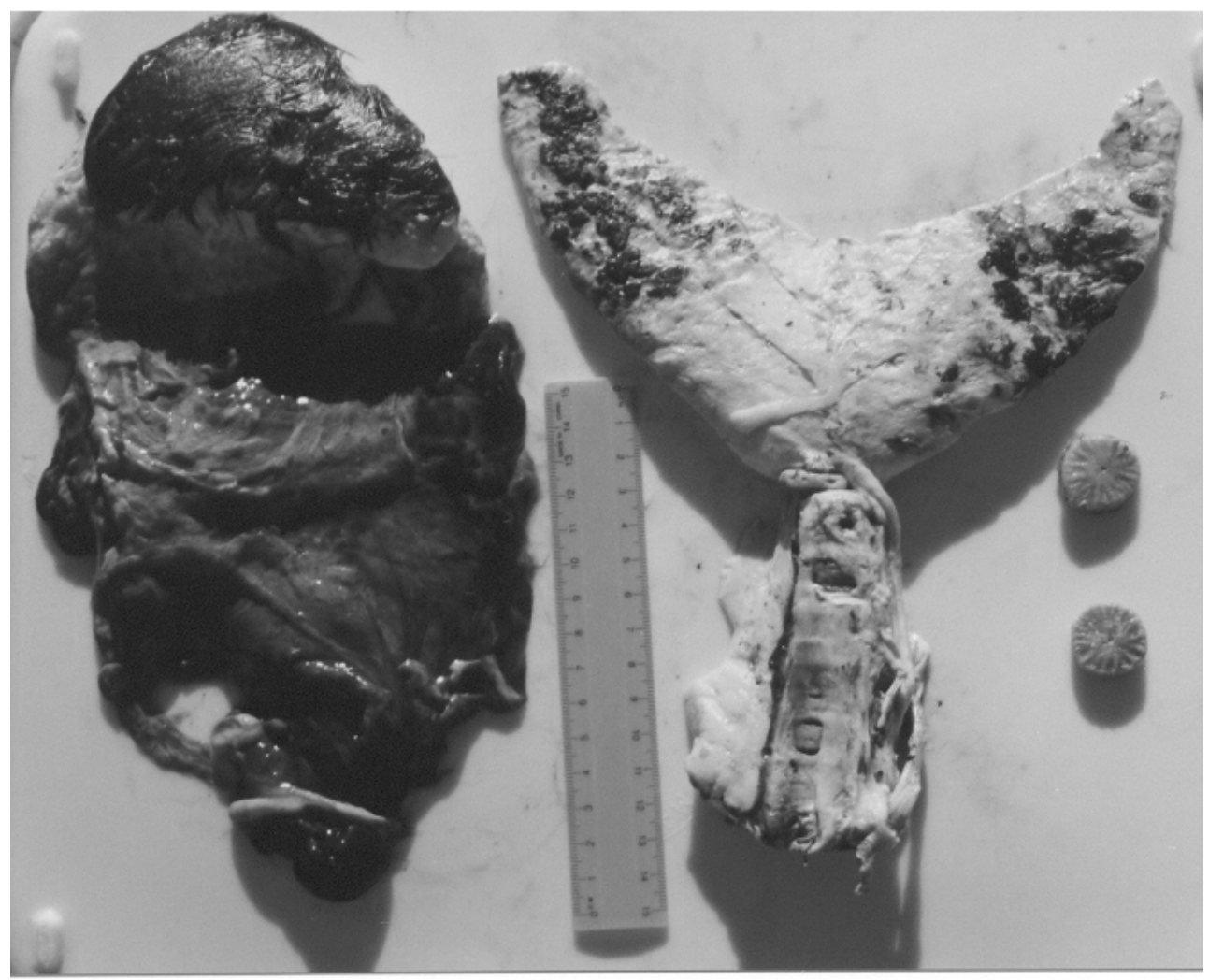

Figure 1. Rest of pinniped and cetacean found in stomach of de Notorhynchus cepedianus captured in San Jorge Gulf, Chubut, Argentina. The reference is a $15 \mathrm{~cm}$ rule.

Besides this paper and Falabella et al. (1996), there is only one previous record of broadnose sevengill shark predation on marine mammals in the southwestern Atlantic. Praderi (1985) reported for the Uruguayan coast that $17 \%$ of the stomach contents of $N$. cepedianus contained franciscanas and that $1 \%$ contained South American sea lions, pointing out that this shark usually predates on marine mammals. In the present study, $15 \%$ of the sampled stomachs contained cetaceans, while $25 \%$ contained pinnipeds. The overall frequency of occurrence of marine mammals in the stomachs was $35 \%$. This confirms Praderi's (1985) statement that marine mammals are a frequent item in the diet of N. cepedianus. Similarly, Ebert (2002) observed that marine mammals composed almost one third of the diet of $N$. cepedianus in cepedianus in California, USA, and in Southern Africa.

Despite our small sample size, pinnipeds were more abundant than cetaceans in the stomach contents. In addition to the limited swimming skills of pinnipeds with respect to cetaceans, this could be also related to the higher relative abundance of pinnipeds in the area. South American sea lions are estimated to number over 70,000 individuals in northern and central Patagonia (Dans et al., 1996, accepted manuscript ${ }^{4}$; Reyes et al., 1999) and the population of southern elephant seals in Península Valdés area was estimated to be around 51,000 individuals (Lewis and Campagna, 2002). In contrast, population size estimates for dusky and Commerson's dolphins (the most abundant small cetaceans in the area), are around 11,000 (Schiavini et al., 1999) and 2,600 respectively (Pedraza et al., submitted ${ }^{5}$ ) considering for both dolphins the upper confidence limit of the estimation. It seems to be a real fact of the higher abundance of pinnipeds in the area with respect to small cetaceans.

In addition to marine mammals, a total of seventeen prey species of fish and squid were identified (Table 3). The percentage frequency of occurrence was $60 \%$ for bony fishes, $35 \%$ for chondrichthyans, $25 \%$ for cephalopods and $5 \%$ for hagfish. The total estimated biomass of fish and squid was $21.2 \mathrm{~kg}$. One Argentine seabass (Acanthistius brasilianus) was recognized by bones without available regression, and thus excluded from this estimation. Even though, this bias can be ignored due to the insignificant amount of remains found.

${ }^{4}$ Dans, S.L., Crespo, E.A., Pedraza, S.N. and Koen Alonso, M. (accepted manuscript) Recovery of the South American sea lion population in northern Patagonia. Canadian Journal of Fishery and Aquatic Science.

${ }^{5}$ Pedraza, S.N., Schiavini, A.C.M., Crespo, E.A., Dans, S.L. and Coscarella, M.A. (Submitted). Abundance of commerson's dolphin (Cephalorhynchus commesonii) in the coasts of Patagonia (Argentina). J. Cetacean Research and Management. 
Table 3. Percentage frequency of occurrence (\%FO) of the consumed fishes and squids by Notorynchus cepedianus.

\begin{tabular}{lcc}
\hline \hline & FISH AND SQUID SPECIES & \\
COMMON NAME & SCIENTIFIC NAME & $\% \mathrm{FO}$ \\
\hline Argentine Shortfin squid & Illex argentinus & 20 \\
Argentine sea bass & Acanthistius brasilianus & 15 \\
South Atlantic bream & Seriolella porosa & 15 \\
Spiny dogfish & Squalus acanthias & 15 \\
Patagonian smoothhound & Mustelus schmitti & 10 \\
Elephant fish & Callorhynchus callorhynchus & 5 \\
Skate & Dipturus flavirostris & 5 \\
Argentine hake & Merluccius hubbsi & 5 \\
Hagfish & Mixine sp. & 5 \\
Silverside & Odonthestes smitti \\
Wreckfish & Stromateus brasiliensis \\
Brazilian sandperch & Poliprion americanus & 5 \\
Raneya & Pseudopercis semifasciata & 5 \\
Tuna fish & Raneya brasiliensis & 5 \\
\hline \hline & Sutterfish & 5
\end{tabular}

In spite of the small size of the sample, it seems that sharks that consumed marine mammals were larger than those that did not (Fig.2). This shark is known to present ontogenetic driven diet change, shifting from bony fishes to chondrichthyans with growth and sexual maturity. Marine mammals then, become increasingly important for larger size classes of $N$. cepedianus (Ebert, 2002).

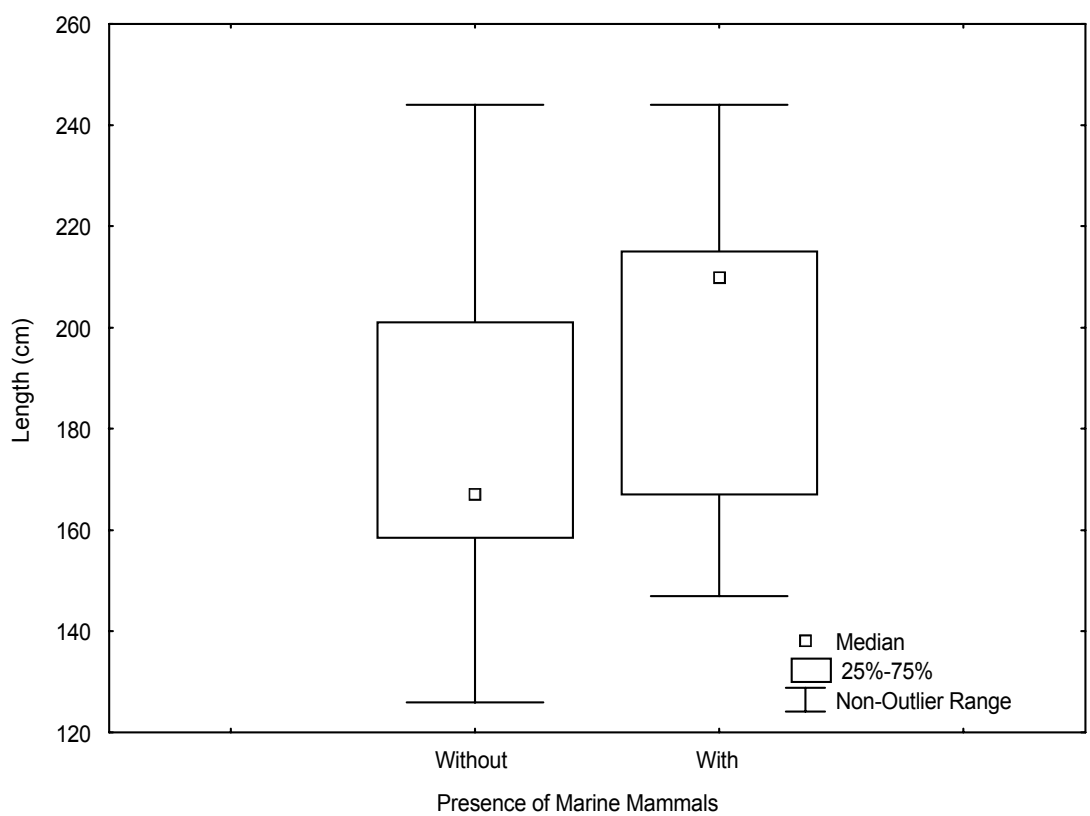

Figure 2. Box-plots showing length of Notorynchus cepedianus with and without presence of marine mammals in stomach contents. 


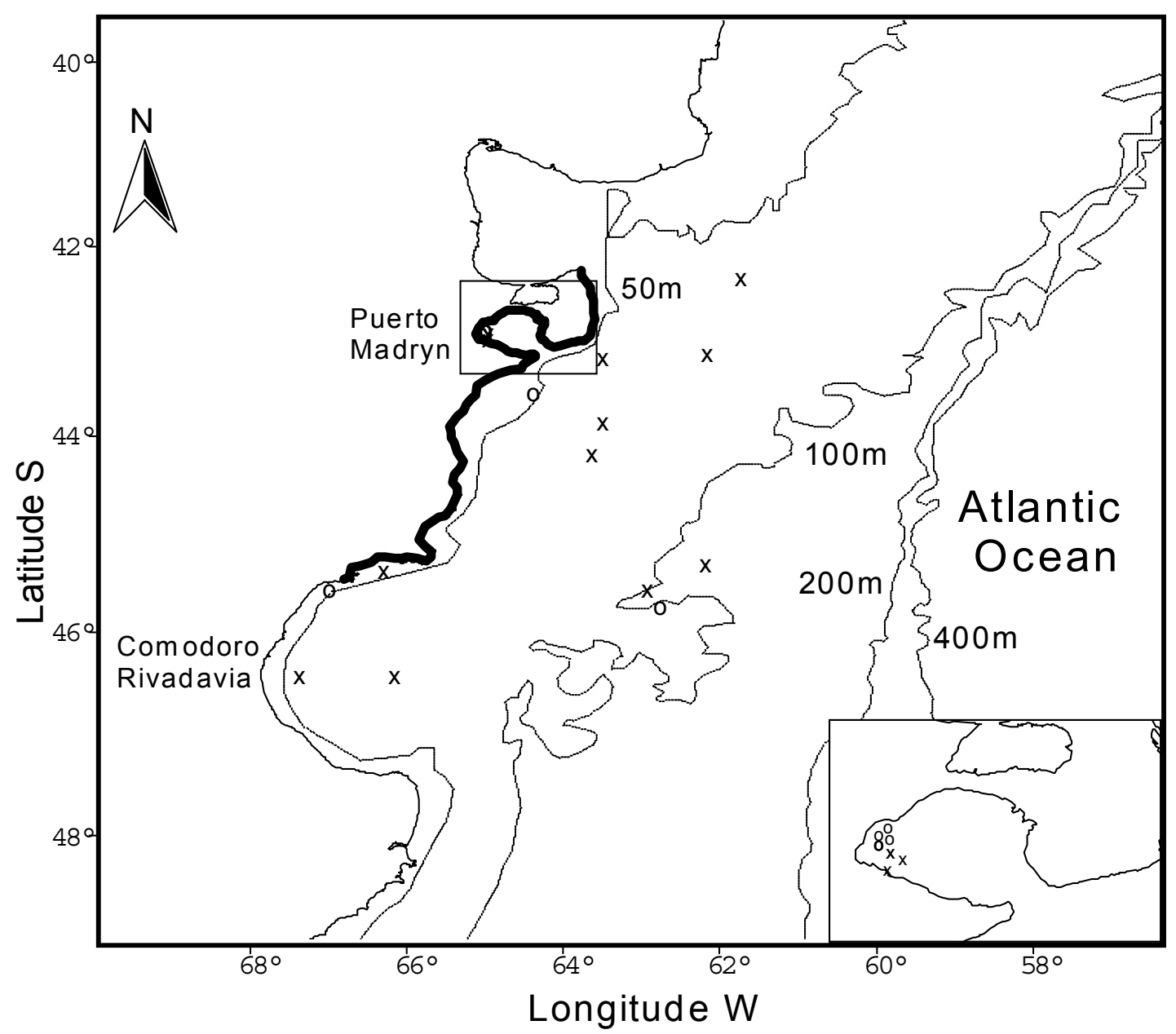

Figure 3. Location of Notorynchus cepedianus caught along the Patagonian shelf, indicating with circles those that consumed marine mammals and with crosses those that did not. Rookeries zones are shown with a thick line on the coast. At the bottom, a detail of Golfo Nuevo is shown.

Although the consumption of marine mammals can be considered important for $N$. cepedianus, there is no direct evidence that predation exist in the study area. Nevertheless, Ebert (1991b) described the predatory behavior of broadnose sevengill shark on marine mammals and other preys in South Africa, confirming that the species actively pursuits or ambushes its preys. The frequency of occurrence of marine mammal items found in shark stomachs appears to be too high to be solely related to scavenging (Ebert, 1991a). Leatherwood et al. (1972) observed shark attacks on dolphins only when they were dead or entangled in fishing nets. Ross and Bass (1971) found that the aggressive behavior of some shark species is more frequent on sick or heavily parasitized dolphins.

Attacks on marine mammals have not been recorded during this investigation; however scars on Commerson's dolphins in Bahía Engaño $\left(43^{\circ} 20^{\prime} S, 65^{\circ} 00^{\prime} \mathrm{W}\right)$ could be attributed to shark bites (LAMAMA, unpublished data). South American sea lions and elephant seals have also been recorded with scars. Whether these wounds were inflicted by N. cepedianus, or resulted from intraspecific aggressive behavior, could not be determined, but considering the high proportion of marine mammals in shark stomach contents, its aggressive behavior, and its relative high abundance in the area, some shark-caused lesions are expected. Obviously it is not discarded that broadnose sevengill shark feed of carrion, since it is a very versatile predator which is known to exploit a broad variety of food resources.

\section{Acknowledgements}

This study was supported by the Agencia Nacional de Promoción Científica y Tecnológica (PICT98 01-04025) and the Consejo de Investigaciones de la Universidad Nacional de la Patagonia (PI 278), Argentina. The Centro Nacional Patagónico (CONICET) provided facilities and logistics for necropsy and analysis. We also acknowledge Alpesca S.A., Harengus S.A., Osvaldo Margagliotti and Inés Elías for providing some of the study material. We also want to thank Susana N. Pedraza and Silvana L. Dans for her critical review, and Mariano Koen-Alonso, Pablo Mariotti, Alejandro Buren and Atila Gosztonyi for their comments or help at different stages of the work. We also want to thank Peter Corkeron, Koen Van Waerebeek and Eduardo R. Secchi who helped very kindly with their reviews to improve the paper. 


\section{References}

Ainley, D.G., Strong, C., Huber, H., Lewis, T. and Morrel, S. (1981) Predation by sharks on pinnipeds at the Farallon Islands. Fishery Bulletin (78): 941-945.

Ainley, D.G., Henderson, R.P., Huber, H.R., Boekelheide, R.J., Allen, S.G. and McElroy, T.L. (1985) Dynamics of white shark/ pinniped interaction in the Gulf of the Farallones. Southern California Academy of Science, Memoirs 9: 109-122.

Boschi, E.E., Fischbach, C.E. and Iorio, M.I. (1992) Catálogo ilustrado de los crustáceos estomatópodos y decápodos marinos de Argentina. Frente Marítimo 10: 7-94.

Brodie, P. and Beck, B. (1982) Predation by sharks on the grey seal (Halichoerus grypus) in Eastern Canada. Canadian Journal of Fishery and Aquatic Science 40: 267-271.

Clarke, M.R. (1986) A hand book for identification of cephalopods beaks. Claerendon Press, London.

Cockcroft, V.G., Cliff, G. and Ross, G.J.B. (1989) Shark predation on Indian Ocean bottlenose dolphin Tursiops truncatus off Natal, South Africa. South African Journal of Zoology 24(4): 305-310.

Compagno, L.J.V. (1984) FAO species catalog. Sharks of the world. An annotated and illustrated catalogue of shark species known to date. Part 1. Hexanchiformes to Lamniformes. FAO Fish. Synop. (125) 4 Rome, 249.

Cortés, E. (1997) A critical review of methods of studying fish feeding based on analysis of stomach contents: application to elasmobranch fishes. Canadian Journal of Fishery and Aquatic Science. 54: 726-738.

Dans, S., Crespo, E., Pedraza, S., González, R. and García, N. (1996) Estructura y tendencia de los apostaderos de lobo marino de un pelo (Otaria flavescens) en el norte de Patagonia. Informes Técnicos del Plan de Manejo Integrado de la Zona Costera Patagónica (13): 1-21.

Ebert, D.A. (1991a) Diet of the sevengill shark Notorynchus cepedianus in the temperate coastal waters of South Africa. South African Journal of Science 11: 565-572.

Ebert, D.A. (1991b) Observation on the predatory behaviour of the sevengill shark Notorynchus cepedianus. South African Journal of Science 11: 455-465.

Ebert, D.A. (2002) Ontogenetic changes in the diet of the sevengill shark (Notorynchus cepedianus). Marine and Freshwater Research 53(2): 517-523.
Heithaus, M.R. (2001) Predator-prey and competitive interactions between sharks and cetaceans: A review. Journal of Zoology (253): 53-68.

Kenyon, W.K. (1981) Monk Seal. pp.195-220 in S. H. Ridgway and R. J. Harrison (Eds) Handbook of marine mammals 2. Academic Press, New York.

Koen Alonso, M., Crespo, E.A., García, N., Pedraza, S. and Coscarella, M. (1998) Diet of dusky dolphins, Lagenorhynchus obscurus, in waters off Patagonia, Argentina. Fishery Bulletin 96: 366-374.

Leatherwood, J.S., Perrin, W., Garvie, R. and LaGrange, J. (1972) Observation of sharks attacking porpoises (Stenella spp. and Delphinus of D. delphis). Naval Undersea Center TN908.

Lewis, M. and Campagna, C. (2002) Los elefantes marinos de Península Valdés. Ciencia Hoy 12 (69): 12-22.

Menni, R.C., Ringuelet, R.A. and Aramburu, R.A. (1984) Peces marinos de la Argentina y Uruguay. Editorial Hemisferio Sur, Buenos Aires, Argentina.

Praderi, R. (1985) Relaciones entre Pontoporia blainvillei (Mammalia: Catacea) y tiburones (Selachii) de aguas uruguayas. Comunicaciones zoológicas del museo de historia natural de Montevideo XI(151): 1-19.

Reyes, L.M., Crespo, E.A. and Szapkievich, V. (1999) Distribution and population size of the Southern sea lion (Otaria flavescens) in central and southern Chubut, Patagonia, Argentina. Marine mammal Science 15(2): 478-493.

Ross, G.J. B. and Bass, A.J. (1971) Shark attack on an ailing dolphin Stenella coeruleoalba Meyen. South African Journal of Science 1971: 413-414.

Schiavini, A., Pedraza, S., Crespo, E., González, R. and Dans, S. (1999) Abundance of dusky dolphins (Lagenorhynchus obscurus) off north and central Patagonia, Argentina, in spring and comparison with incidental catch in fisheries. Marine Mammal Science 15(3): 828-839.

Volpedo, A.V. and Echeverría, D.D. (2000). Catálogo y claves de otolítos para la identificación de peces del Mar Argentino: 1. Peces de importancia económica. Editorial Dunken, Buenos Aires, Argentina.

Würsig, B. and Würsig, M. (1980). Behavior and ecology of the dusky dolphin, Lagenurhynchus obscurus, in the South Atlantic. Fishery bulletin 77(4): 871-890. 
